\title{
Association between temporomandibular disorder symptoms and demographic, dental and behavioral factors in the elderly: a population- based cross-sectional study
}

\author{
Associação entre sintomas de disfunção temporomandibular e fatores demográficos, \\ odontológicos e comportamentais em idosos: um estudo transversal de base populacional
}

Claudia Maria Czernaik ${ }^{1}$, Francisco Wilker Mustafa Gomes Muniz ${ }^{2}$, Paulo Roberto Grafitti Colussi ${ }^{3}$, Cassiano Kuchenbecker Rösing ${ }^{4}$, Eliane Lucia Colussi ${ }^{5}$

\section{ABSTRACT}

BACKGROUND AND OBJECTIVES: To assess the prevalence of temporomandibular dysfunction symptoms and the associated factors in the elderly of a city in southern Brazil.

METHODS: A cross-sectional observational study performed in residential homes, with probabilistic cluster sample, interviewed and examined 287 seniors aged from 65 to 74 years in the city of Cruz Alta, state of Rio Grande do Sul, Brazil. The Fonseca Anamnestic Index was used for temporomandibular dysfunction analysis, as well as a structured questionnaire for socioeconomic conditions and an oral health clinical examination. Either Chisquare or Mann-Whitney tests assessed associations between the dependent and independent variables and presented by frequency distribution. Uni- and multivariate analyses were performed to verify the association between temporomandibular dysfunction risk and explanatory variables. For all statistical analyses, a $5 \%$ significance level was adopted.

RESULTS: The prevalence of temporomandibular dysfunction symptoms was $55.1 \%$. In the final multivariate model, age $\geq 70$ years $(\mathrm{RP}=0.674 ; 95 \% \mathrm{CI}: 0.516-0.881)$ showed as a protection factor against temporomandibular dysfunction, and the average of tooth loss (RP=1.022; 95\% CI: 1.004 - 1.039) showed as a risk factor for temporomandibular dysfunction in relation to their respective controls.

1. Universidade de Passo Fundo, Faculdade de Educação Física e Fisioterapia, Programa de Pós-Graduaçáo em Envelhecimento Humano, Passo Fundo, RS, Brasil.

2. Universidade Federal de Pelotas, Faculdade de Odontologia, Departamento de Semiologia e Clínica, Pelotas, RS, Brasil.

3. Universidade de Passo Fundo, Faculdade de Odontologia, Departamento de Periodontia, Passo Fundo, RS, Brasil.

4. Universidade Federal do Rio Grande do Sul, Faculdade de Odontologia, Departamento de Periodontia, Porto Alegre, RS, Brasil.

5. Universidade de Passo Fundo, Programa de Pós-Graduação em Envelhecimento Humano, Passo Fundo, RS, Brasil.

Submitted in January 22, 2018.

Accepted for publication on June 22, 2018.

Conflict of interests: none - Sponsoring sources: none.

Correspondence to:

BR 285, Săo José

99052-900 Passo Fundo, RS, Brasil.

E-mail: claudiaczernaik15@hotmail.com

(c) Sociedade Brasileira para o Estudo da Dor
CONCLUSION: The findings of the present study showed a high prevalence of temporomandibular dysfunction symptoms. Age and tooth loss were associated with higher risk of temporomandibular dysfunction. The results suggested the need for improvement in oral health conditions of the elderly and the importance of further epidemiological studies about temporomandibular dysfunction in this population.

Keywords: Aging, Oral health, Prevalence, Risk factors, Temporal joint dysfunction syndrome.

\section{RESUMO}

JUSTIFICATIVA E OBJETIVOS: Avaliar a gravidade dos sintomas de disfunção temporomandibular e seus fatores em idosos de uma cidade do sul do Brasil.

MÉTODOS: Estudo observacional transversal de domicílios residenciais, com amostra probabilística por conglomerado, entrevistou e examinou 287 idosos, com idade entre 65 e 74 anos da cidade Cruz Alta, estado do Rio Grande do Sul, Brasil. O Índice Anamnésico de Fonseca foi utilizado para avaliação da disfunção temporomandibular, além de um questionário estruturado para condiçôes socioeconômicas e um exame clínico de saúde bucal. As associações entre a variável dependente e a independente foram avaliadas pelos testes de Qui-quadrado ou Mann-Whitney, apresentadas por meio da distribuição de frequências. As análises uni e multivariada foram realizadas para verificar a associação entre a disfunção temporomandibular e as variáveis exploratórias. Para todas as análises, o nível de significância foi de 5\%. RESULTADOS: A prevalência de sintomas de disfunçáo temporomandibular foi de $55,1 \%$. No modelo multivariado final, a idade $\geq 70$ anos (RP $=0,674 ; 95 \%$ IC: $0,516-0,881)$ apresentou-se como fator de proteção para disfunção temporomandibular e a média de perda dentária (RP=1,022; 95\% IC: 1,004 - 1,039) apresentou-se como fator de risco para disfunção temporomandibular em relação a seus respectivos controles.

CONCLUSÁO: Os resultados demonstraram alta prevalência de sintomas de disfunção temporomandibular. A idade e a média de perda dentária foram associadas à disfunção temporomandibular. Os resultados sugerem melhorias nas condiçôes de saúde bucal dos idosos e a importância de estudos epidemiológicos sobre disfunção temporomandibular nessa população.

Descritores: Envelhecimento, Fatores de risco, Prevalência, Saúde bucal, Síndrome da disfunçáo da articulaçáo temporomandibular. 


\section{INTRODUCTION}

In recent decades, population aging has ceased to be a characteristic only of developed countries. In this sense, the World Health Organization (WHO) ${ }^{1}$ estimate that Brazil will have the sixth largest population of old people in a short period. Therefore, it is fundamental to observe the peculiarities inherent in this life cycle ${ }^{2}$, since they effectively represent a great socioeconomic impact for the country and a challenge for the managers of public policies ${ }^{3-5}$. With the advancement of the aging process, morphophysiological changes occur in the body more rapidly, which increases the predisposition to diseases. These changes may also affect the stomatognathic system (SS), including the temporomandibular joints (TMJ). Among these changes are temporomandibular disorders (TMD), which make up a group of diseases that affect the masticatory muscles and other structures related to SS. Some studies report TMD as the second major cause of musculoskeletal injuries, with an important role in the occurrence of orofacial pain (OFP) and in the incapacitation of daily activities ${ }^{6}$. The etiology of TMD is multifactorial and dynamic. This includes emotional stress, occlusal interference, tooth loss, poor tooth position, parafunctional activities, masticatory muscle disorder and even a combination of one or more factors ${ }^{7,8}$. The most common signs and symptoms of TMD are pain in masticatory muscles or TMJ, joint noise, sensitivity throughout the SS and cervical musculature, headache, limited capacity of mandibular movements and deviations in movement patterns. Pain is the most frequent symptom of TMD, with a higher prevalence in the masticatory muscles than in the joints. In relation to the elderly, about $12 \%$ present muscle pain, and $5 \%$ joint pain, and the OFP can compromise the functionality and can impact the quality of life (QoL) $)^{9,10}$.

Over time, studies have been conducted to evaluate the etiology, prevalence, and ways of treating TMD ${ }^{11-14}$. However, there seems to be no consensus, especially with regard to its prevalence. This can be attributed to the methodologies applied, the diagnostic methods used and other reasons ${ }^{15,16}$. Therefore, some tools were developed to evaluate, diagnose and estimate the prevalence of TMD, including the Fonseca Anamnestic Index (FAI) ${ }^{17}$. It is a tool developed in Brazil, validated and frequently used in Brazilian epidemiological studies. It is useful in epidemiological studies conducted in large populations ${ }^{18}$ because of its simplicity and its shorter application time.

Home-based studies have shown a prevalence of TMD between $33^{19,20}$ and $63 \%{ }^{21,22}$, and one of the main determining factors is the oral health condition. In Brazil, the oral health conditions of the elderly are precarious, with a high average of dental loss, as well as the percentage of elderly with a need for prosthetic rehabilitation ${ }^{23}$. This may cause an imbalance in the functioning of the masticatory system and lead to $\mathrm{TMD}^{24,25}$. In addition, there are other factors associated with TMD in the elderly, such as precarious socioeconomic and general health conditions ${ }^{26-28}$. It should be noted the great regional differences in oral health observed in Brazil ${ }^{23}$. In this context, it is important to know the severity of TMD symptoms and their risk factors among the elderly in different Brazilian regions.
This study aimed to evaluate the prevalence of TMD symptoms and their associated factors in the elderly in a city in the southern region of Brazil.

\section{METHODS}

Observational cross-sectional study of residential homes, who interviewed and examined elderly between 65 and 74 years old ${ }^{29}$ in the urban area of Cruz Alta. The municipality is located in the north of the state of Rio Grande do Sul, Brazil. The city has a population of approximately 62,821 inhabitants $^{30}$. Of these, 3,730 are in the age group between 65 and 74 years old, $42 \%$ of males and $58 \%$ of females. More than $95 \%$ of the population lives in the urban area. The Gini Index in 2010 was $0.5419^{31}$.

A sample calculation was performed considering the elderly population between 65-74 years old, assuming an alpha error of $5 \%$, at a $95 \%$ confidence level, an expectation of moderate/ severe TMD prevalence of $19 \%{ }^{21}$ and an attrition rate of $15 \%$, totalizing a sample number of 273 elderly.

A probabilistic sample per conglomerate was conducted to visit 300 homes. The city, which has 68 neighborhoods or towns, was divided into five areas, numbered from zero to four, according to the number of elderly inhabitants of each neighborhood or town and the percentage of elderly in the area. A total of 17 neighborhoods or towns were randomly selected (25\%), according to the number of towns or neighborhoods in the area, obeying the proportionality of the elderly (Table 1). Each town or neighborhood that was selected was divided into blocks, which were numbered. The blocks were randomly selected randomly. The corners of the randomly selected blocks were numbered from one to four, and a new draw was conducted to determine the starting point of the first interview. After the first interview, the visits continued clockwise until the completion of the planned work. When necessary, new blocks were selected to contemplate the approximate number of homes to be visited.

The criteria adopted for inclusion in the study were those between 65 and 74 years old and residing in homes in the neighborhoods or towns that were randomly selected. The present study included individuals with physical, medical and mental conditions that enabled their achievement. If there were more people in the home who fit the eligibility criteria, they would also be included in the study. Residential buildings could include only one apartment in the study. In case of absence on the day of data collection, two further attempts would be made per home. The study excluded commercial and uninhabited homes, visitors in the house, and at a long-stay institution for the elderly (ILPI). A structured questionnaire was applied that included sociodemographic, behavioral data, among others, obtained through the use of blocks of questions from the PCATool-SB Brazil toll ${ }^{32}$. The tool used to evaluate the TMD was the $\mathrm{FAI}^{17}$. The oral health conditions were evaluated by the counting of teeth and by the verification of the use and need of dental prosthesis. Clinical examinations of tooth counting and the use and need for prosthesis were performed with the aid of a wooden spatula, without the use of artificial lighting and without the aid of mirrors. The tooth counting was performed excluding the third molar. 
Table 1. Number of elderly inhabitants of each neighborhood

\begin{tabular}{|c|c|c|c|c|c|c|}
\hline Area & $\begin{array}{c}\text { Total of elderly population } \\
\text { over } 60 \text { years old } \\
\text { in neighborhoods or towns }\end{array}$ & $\begin{array}{c}\% \text { of elderly in the } \\
\text { area }\end{array}$ & $\begin{array}{c}\text { Number of } \\
\text { neighborhoods or } \\
\text { towns }\end{array}$ & $\begin{array}{c}\text { Number of } \\
\text { neighborhoods or } \\
\text { towns selected }\end{array}$ & $\begin{array}{l}\text { Number of homes } \\
\text { selected by town } \\
\text { or neighborhood }\end{array}$ & $\begin{array}{l}\text { Total number of } \\
\text { homes per area }\end{array}$ \\
\hline 0 & $>301$ & 12.90 & 1 & 1 & 39 & 39 \\
\hline 1 & Between 301 and 202 & 19.68 & 5 & 2 & 30 & 60 \\
\hline 2 & Between 201 and 102 & 29.20 & 14 & 3 & 29 & 87 \\
\hline 3 & Between 101 and 52 & 26.32 & 24 & 6 & 14 & 84 \\
\hline 4 & $\leq 51$ & 11.90 & 24 & 5 & 6 & 30 \\
\hline Total & & 100.00 & 68 & 17 & & 300 \\
\hline
\end{tabular}

Subjects were examined and interviewed in July and August 2016 by teams composed of an interviewer and an oral health examiner. The examiners were previously trained to ensure uniform data collection. The training consisted of theoretical classes and discussion on the questions of the questionnaire, as well as explanations about oral health exams. Before the data collection, there was a training session with the application of the questionnaire and oral health exam in patients at the Dental School of the University of Passo Fundo (UPF). The inter-examiner reproducibility of the clinical examination was verified in $5 \%$ of those examined, chosen by random draw. The Kappa index for the need for a prosthesis and for the tooth counting was 1 and 0.85 , respectively.

The dependent variable was the prevalence of TMD symptoms, through the FAI tool. The tool classifies individuals by severity of symptoms as the absence of TMD, mild TMD, moderate TMD, and severe TMD. For data analysis, the elderly were categorized into three groups: Absence of TMD, mild TMD, and moderate/severe TMD. The independent variables included sociodemographic conditions, behavioral aspects and oral and general health conditions.

Age was dichotomized into two groups, one with $\leq 69$ years old and another com $\geq 70$ years old. This division was based on the median age found in this sample. Ethnicity/skin color was categorized as white or non-white. The non-white group included the elderly who referred to as black, yellow, brown or indigenous. The educational level was categorized as low educational level, which includes the elderly with at most complete elementary school, including the illiterate; average education, for those with incomplete or complete high school; and high education, for the elderly with incomplete or complete higher education.

The need for prosthesis was categorized as yes, for the need for some kind of prosthesis, and no for the elderly without any need for prosthesis. The use of prosthesis in edentulous was categorized as follows: teeth, the elderly who had teeth independently of the use of partial dental prostheses, edentulous users of two total dental prostheses and edentulous users of only one total dental prosthesis or no total dental prosthesis users. The item smoking was categorized into two groups, one with elderly people with no history of smoking and the other with elderly people who currently smoke or have smoked. The health problems were categorized into two groups, one with elderly people who reported not having or not knowing if they had health problems and another group with elderly people who said they had a health problem. The use of drugs was categorized into two groups, one with elderly patients who reported using one or more drugs and another who reported not using.
This study was reviewed and approved by the Ethics Committee of the University of Passo Fundo (UPF). All the elderly read and signed the Free and Informed Consent Form (FICT) before participating in the study.

\section{Statistical analysis}

Data analysis was performed using the statistical package SPSS 21 (SPSS Inc., Chicago, United States). The associations between the dependent variable and the independent variables were evaluated by the Chi-square or Mann-Whitney tests, presented by frequency distribution. Univariate and multivariate analyzes were performed using Poisson regression with a robust variance to verify the association between the dependent variable and the independent variables. Only those variables that presented $p<0.20$ in the univariate analysis were included in the multivariate model. The maintenance of the independent variables in the final model was determined by the combination of $\mathrm{p}$ value $<0.05$ and analysis of effect modifications. The multicollinearity analyzes between the independent variables were performed, and none were observed.

\section{RESULTS}

A total of 287 elderly was interviewed and examined in 260 homes, of the 292 homes visited. The response rate of this study was $89.04 \%$. In 32 homes there was a refusal to participate in the study (Figure 1). The average age of the sample was $69.30 \pm 3.52$ years old, of which 102 (35.5\%) were male, and 185 (64.5\%) were female. Regarding ethnicity/skin color, 196 (68.3\%) declared themselves white, and $91(31.7 \%)$ reported being not white. In relation to educational level, 190 (62.6\%) had a low educational level, of which, 17 (5.9\%) declared themselves illiterate. About $60 \%$ of the elderly were married, while about $40 \%$ were divided into single, divorced or widower. $76.3 \%$ of the elderly were retired. Some type of health problem was observed in $86.4 \%$ of the elderly. Also, approximately $42 \%$ reported a history of smoking exposure (Table 2 ).

A total of 158 (55.1\%) elderly with TMD symptoms were diagnosed, of whom 120 (41.8\%) had mild TMD, 29 (10.1\%), had moderate TMD and $9(3.2 \%)$ had severe TMD. For the analysis of the results, 129 (44.9\%) elderly were considered without TMD, 120 (41.8\%) had mild TMD, and 38 (13.3\%) had moderate/severe TMD. Age $(\mathrm{p}=0.036)$ and reporting of a general health problem $(\mathrm{p}<0.001)$ (Table 2$)$ were significantly associated with TMD. Gender $(\mathrm{p}=0.392)$, skin color $(\mathrm{p}=0.429)$, educational level $(p=0.236)$, need for prosthesis $(p=0.246)$ and access to the dentist in the last 12 months $(p=0.281)$ did not present statistical significance with symptoms of TMD (Table 3). 


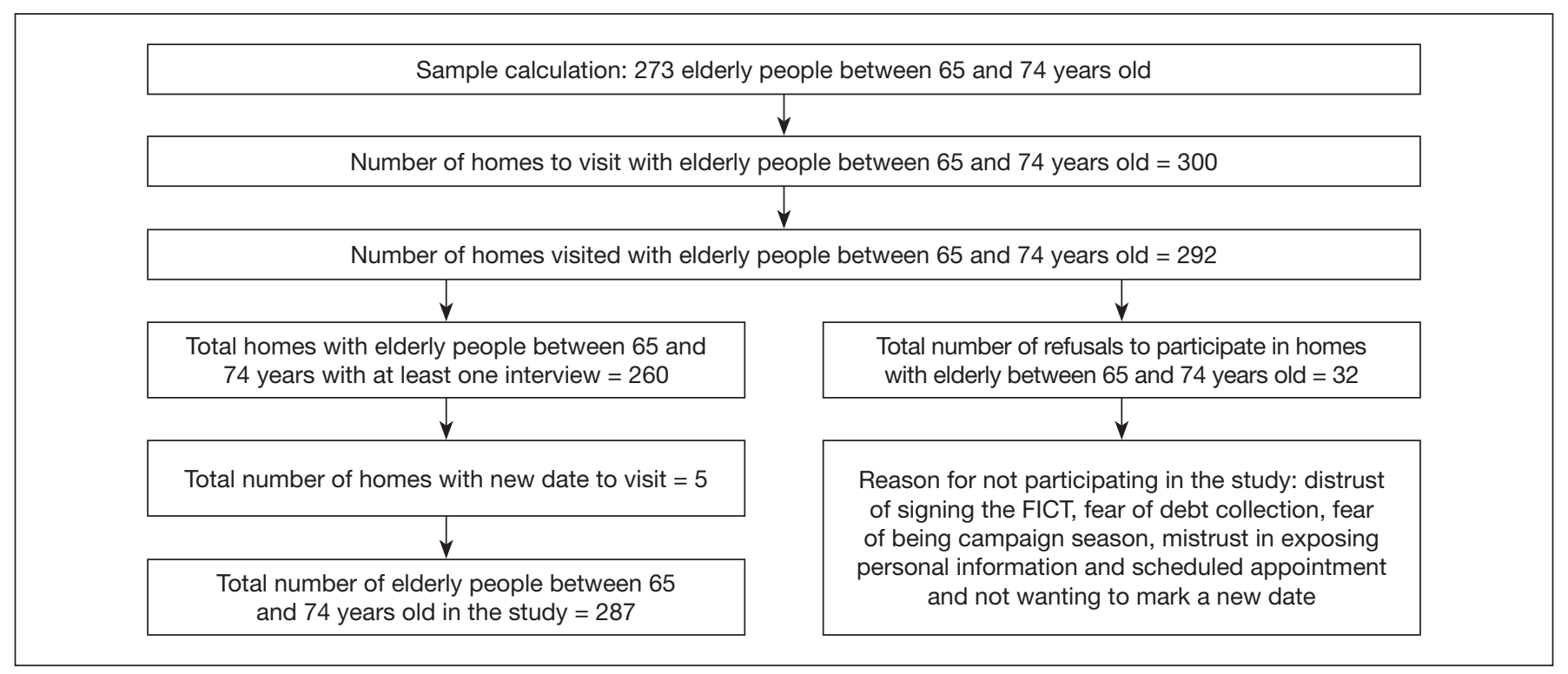

Figure 1. Study flowchart

FICT = Free and Informed Consent Form.

Table 2. Demographic characteristics of the sample and frequency distribution of exposures in relation to the temporomandibular dysfunction outcome among elderly individuals between 65 and 74 years old, Cruz Alta, 2016

\begin{tabular}{|c|c|c|c|c|}
\hline \multirow[t]{2}{*}{ Variables } & $\begin{array}{l}\text { Without TMD } \\
(n=129 ; 44.9 \%)\end{array}$ & $\begin{array}{c}\text { Mild TMD } \\
(\mathrm{n}=120 ; 41.8 \%)\end{array}$ & $\begin{array}{l}\text { Moderate/severe TMD } \\
\quad(n=38 ; 13.2 \%)\end{array}$ & $\mathrm{p}$ value \\
\hline & n (\%) & n (\%) & n (\%) & \\
\hline Age (years old) & & & & $0.036^{*}$ \\
\hline$\leq 69$ & $58(45.0)$ & $73(60.8)$ & $22(57.9)$ & \\
\hline$\geq 70$ & $71(55.0)$ & 47 (39.2) & $16(42.1)$ & \\
\hline Gender & & & & $0.392^{*}$ \\
\hline Female & $78(60.5)$ & $80(66.7)$ & $27(71.1)$ & \\
\hline Ethnicity/skin color & & & & $0.429^{*}$ \\
\hline Not white & $46(35.7)$ & $34(28.3)$ & $11(28.9)$ & \\
\hline White & $83(64.3)$ & $86(71.7)$ & $27(71.1)$ & \\
\hline Low & $24(18.6)$ & $14(11.7)$ & 7 (18.4) & \\
\hline Marital status & & & & $0.587^{*}$ \\
\hline Married & $69(53.5)$ & $76(63.3)$ & $20(52.6)$ & \\
\hline Single & 15 (11.6) & $10(8.3)$ & $6(15.8)$ & \\
\hline Divorced & $18(14.0)$ & $10(8.3)$ & $4(10.5)$ & \\
\hline Widower & $27(20.9)$ & $24(20.0)$ & $8(21.1)$ & \\
\hline Retired & & & & $0.396^{*}$ \\
\hline Yes & $103(79.8)$ & $87(72.5)$ & $29(76.3)$ & \\
\hline No & $26(20.2)$ & $33(27.5)$ & $9(23.7)$ & \\
\hline
\end{tabular}


Table 2. Demographic characteristics of the sample and frequency distribution of exposures in relation to the temporomandibular dysfunction outcome among elderly individuals between 65 and 74 years old, Cruz Alta, 2016 - continuação

\begin{tabular}{|c|c|c|c|c|}
\hline \multirow[t]{2}{*}{ Variables } & $\begin{array}{l}\text { Without TMD } \\
(n=129 ; 44.9 \%)\end{array}$ & $\begin{array}{c}\text { Mild TMD } \\
(\mathrm{n}=120 ; 41.8 \%)\end{array}$ & $\begin{array}{c}\text { Moderate/severe TMD } \\
\quad(n=38 ; 13.2 \%)\end{array}$ & $\mathrm{p}$ value \\
\hline & n (\%) & $\mathrm{n}(\%)$ & $\mathrm{n}(\%)$ & \\
\hline No & $92(71.3)$ & $83(69.2)$ & $26(68.4)$ & \\
\hline Yes & $37(28.7)$ & $37(30.8)$ & $12(31.6)$ & \\
\hline Edentulous with two prostheses & $34(26.4)$ & $31(25.8)$ & $8(21.6)$ & \\
\hline Edentulous without prosthesis or only with a prosthesis & $3(2.3)$ & $6(5.0)$ & $3(8.1)$ & \\
\hline Access to the dentist in the last 12 months & & & & $0.281^{*}$ \\
\hline Yes & $66(51.2)$ & $55(45.8)$ & $14(36.8)$ & \\
\hline Smokers and ex-smokers & $78(60.5)$ & $70(58.3)$ & $18(47.4)$ & \\
\hline Any health problem & & & & $0.001^{*}$ \\
\hline Yes & $102(79.1)$ & $108(90.0)$ & $38(100.0)$ & \\
\hline No/do not know & 27 (20.9) & $12(10.0)$ & $0(0.0)$ & \\
\hline Drug use & & & & $0.355^{\star}$ \\
\hline No/do not know & 27 (20.9) & $18(15.0)$ & $5(13.2)$ & \\
\hline Yes & $102(79.1)$ & $102(85.0)$ & 33 (86.8) & \\
\hline
\end{tabular}

Table 3. Univariate analysis model associating exposures in relation to temporomandibular dysfunction among elderly between 65 and 74 years old, Cruz Alta, 2016

\begin{tabular}{|c|c|c|c|c|}
\hline Variables & $\begin{array}{c}\text { Mild TMD } \\
\text { Prevalence ratio }(95 \% \mathrm{Cl})\end{array}$ & $p$ value & $\begin{array}{c}\text { Moderate/severe TMD } \\
\text { Prevalence ratio }(95 \% \mathrm{Cl})\end{array}$ & $\mathrm{p}$ value \\
\hline \multicolumn{5}{|c|}{ Age (years old) } \\
\hline$\leq 69$ & Ref. & 0.014 & Ref. & 0.165 \\
\hline$\geq 70$ & $0.715(0.546-0.936)$ & & $0.669(0.379-1.180)$ & \\
\hline \multicolumn{5}{|l|}{ Gender } \\
\hline Male & Ref. & 0.320 & Ref. & 0.246 \\
\hline Female & $1.152(0.872-1.522)$ & & $1.449(0.774-2.713)$ & \\
\hline \multicolumn{5}{|c|}{ Ethnicity/skin color } \\
\hline Not white & Ref. & 0.231 & Ref. & 0.450 \\
\hline White & $1.197(0.892-1.608)$ & & $1.272(0.682-2.373)$ & \\
\hline \multicolumn{5}{|l|}{ Education } \\
\hline High & Ref. & & Ref. & \\
\hline Average & $1.062(0.612-1.842)$ & 0.830 & $0.782(0.295-2.074)$ & 0.620 \\
\hline Low & $1.448(0.932-2.248)$ & 0.099 & $1.085(0.520-2.265)$ & 0.827 \\
\hline \multicolumn{5}{|c|}{ Marital status } \\
\hline Married & Ref. & & Ref. & \\
\hline Single & $0.763(0.461-1.246)$ & 0.294 & $1.271(0.584-2.770)$ & 0.546 \\
\hline Divorced & $0.681(0.405-1.147)$ & 0.149 & $0.809(0.308-2.127)$ & 0.668 \\
\hline Widower & $0.898(0.646-1.249)$ & 0.522 & $1.017(0.495-2.091)$ & 0.963 \\
\hline \multicolumn{5}{|l|}{ Retirement } \\
\hline Yes & Ref. & 0.153 & Ref. & 0.634 \\
\hline No & $1.222(0.928-1.607)$ & & $1.170(0.612-2.238)$ & \\
\hline
\end{tabular}


Table 3. Univariate analysis model associating exposures in relation to temporomandibular dysfunction among elderly between 65 and 74 years old, Cruz Alta, 2016 - continuação

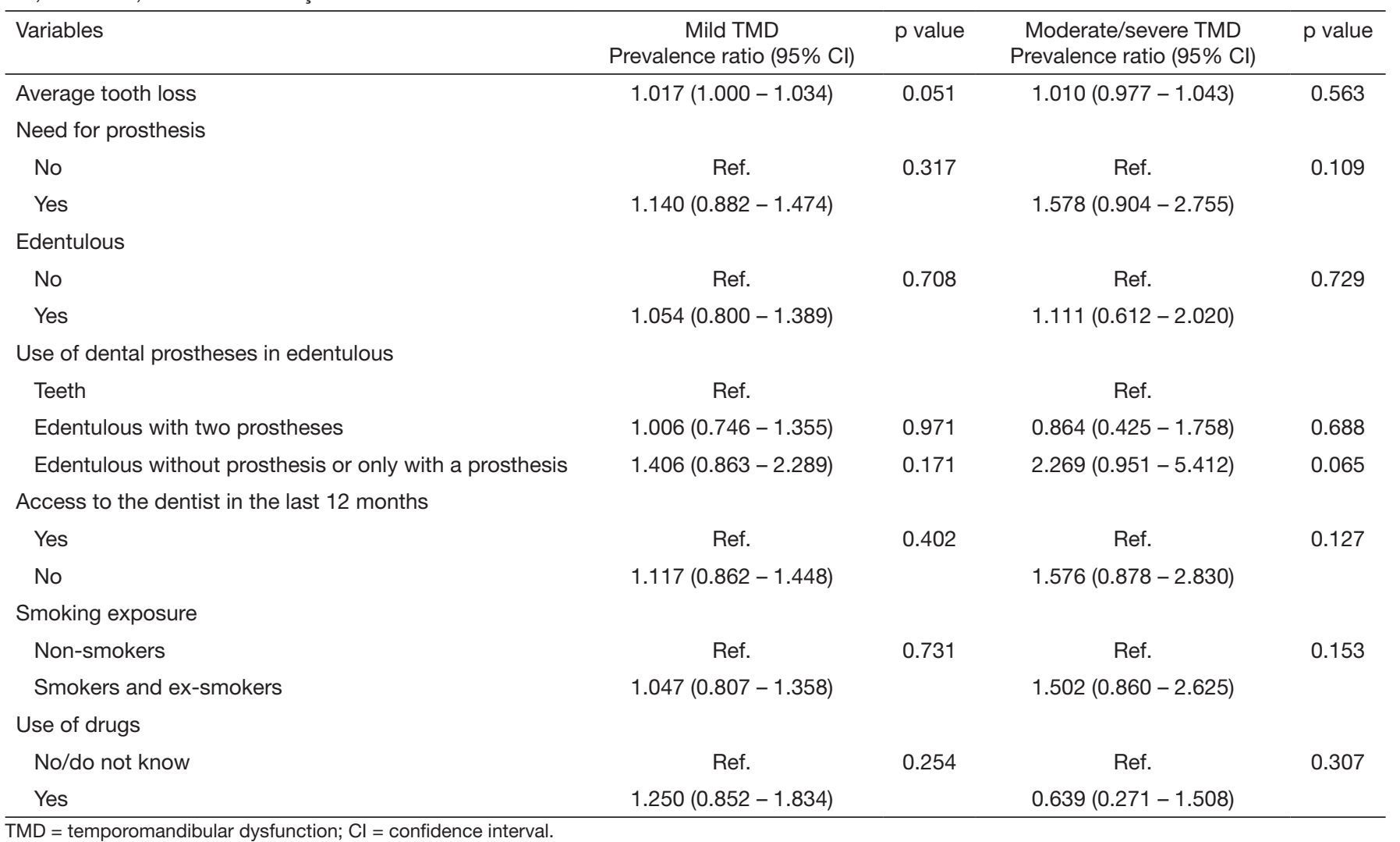

Age was significantly associated with a higher prevalence of mild TMD. The highest age ( $\geq 70$ years old) was shown to be a protective factor for mild TMD when compared to individuals without TMD. Elderly patients between $\geq 70$ years old had a prevalence ratio of $28.5 \%$ lower when compared to the elderly with up to 69 years $(\mathrm{p}=0.014)$. None of the independent variables were significantly associated with moderate/severe TMD (Table 4).

The following variables were included in the initial multivariate model: age, education, marital status, retirement, average dental loss, need for prosthesis and use of dental prosthesis in edentulous. In the final model, only age and average tooth loss remained associated with mild TMD. High age ( $\geq 70$ years) has been shown to be a protective factor against mild TMD. The elderly with a more advanced age had a 32.6\% lower prevalence rate when compared with the elderly with up to 69 years old $(\mathrm{p}=0.004)$. Dental loss has been shown to be a risk factor for mild TMD when compared to the elderly without TMD. For each lost tooth, the individual presented a $2.2 \%$ higher prevalence ratio $(p=0.013)$. In this model, no statistically significant association was observed for moderate/severe TMD.

\section{DISCUSSION}

The evaluation of TMD symptoms is important because it makes possible the early recognition of the patients, which can help in the prevention and/or the control of their chronicity and possible degenerations. This is particularly important in the elderly, as this age group has been increasing in the last decades. In addition, data from this study may assist in the planning of public health policies.

Some symptom of TMD was detected in 158 (55.1\%) elderly. The results of this study demonstrated a high prevalence of

Table 4. Multivariate analysis model associating exposures in relation to temporomandibular dysfunction among elderly between $65-74$ years old, Cruz Alta, 2016

\begin{tabular}{|c|c|c|c|c|}
\hline Variables & $\begin{array}{c}\text { Mild TMD } \\
\text { Prevalence ratio }(95 \% \mathrm{Cl})\end{array}$ & $p$-value & $\begin{array}{c}\text { Moderate/severe TMD } \\
\text { Prevalence ratio }(95 \% \mathrm{Cl})\end{array}$ & $p$-value \\
\hline \multicolumn{5}{|l|}{ Age (years) } \\
\hline$\leq 69$ & Ref. & 0.004 & Ref. & 0.121 \\
\hline$\geq 70$ & $0.674(0.516-0.881)$ & & $0.638(0.361-1.125)$ & \\
\hline Average tooth loss & $1.022(1.004-1.039)$ & 0.013 & $1.015(0.983-1.048)$ & 0.375 \\
\hline
\end{tabular}

$\mathrm{TMD}=$ temporomandibular dysfunction; $\mathrm{Cl}$ = confidence interval. 
TMD symptoms and had similar characteristics to other studies that used FAI, both in home-based studies ${ }^{11,15}$ and in others developed in universities or coexistence centers ${ }^{19,20,33}$, in which there is a prevalence around $50 \%$, regardless of severity. Likewise, cross-sectional studies using other tools and/or clinical exams also reported similar prevalences ${ }^{20,22,34-36}$. In general, regardless of the study design and tools used, the prevalence of TMD was high among the elderly.

Epidemiological studies have indicated a high prevalence of TMD. However, it is estimated that the number of people who really need some kind of treatment turn around 10 to $15 \%$. This percentage generally includes those with moderate/severe TMD symptoms ${ }^{7,17}$. In this study, the prevalence of moderate/ severe TMD symptoms was $13.3 \%$. These results are similar to other studies, regardless of the tool used ${ }^{15,19,22}$. These individuals should be in some kind of treatment with the objective of reducing pain, increasing joint amplitude, preventing new lesions, reducing morbidities and improving $\mathrm{QoL}^{37,38}$. Poor oral health conditions are among the main causes of TMD. In this study, tooth loss was associated with a higher risk of mild TMD. In fact, some studies confirm that the loss of natural teeth has been considered as one of the main risk factors for $\mathrm{TMD}^{24,25,39}$, since several oral problems are directly related to the lack of natural teeth. Data from the last national survey showed that the elderly between 65 and 74 years old had an average of 25.29 lost teeth and a prevalence of $54 \%$ of edentulism $^{23}$. In addition, the majority of Brazilian elderly still need rehabilitation with some type of prosthesis ${ }^{40}$. Although there was no statistically significant association with TMD, the need for a prosthesis is a direct result of dental losses, and probably one of the factors associated with TMD.

Likewise, age was statistically associated with the prevalence of TMD symptoms. Being $\geq 70$ years old was a protective factor for mild TMD. These results were similar to other investigations that associated older age as a protective factor for $\mathrm{TMD}^{19,22}$. With regard to age, it is believed that older people tend to develop better resilience in SS, adapting to the changes resulting from aging ${ }^{5,41}$. Moreover, in the course of the aging process, the elderly, for the most part, tend to conform to the deterioration of their health and, therefore, believe that oral problems are an unavoidable consequence of aging ${ }^{4,42}$. In this study, only elderly individuals between 65 and 74 years old were included, based on the criteria recommended by the WHO for epidemiological studies on oral health ${ }^{29}$. This strategy is recommended, as it allows comparisons between several studies, in addition to making sampling strategy viable.

In contrast, this study found no statistically significant association between gender and TMD symptoms. These results were similar to those of other studies that found that gender differences in relation to TMD were not as important for the older age groups ${ }^{24,43}$. Some studies have associated educational level and income with $\mathrm{TMD}^{11,14}$, although the educational level has not been associated with TMD in this study. However, tooth loss can be used as a proxy for educational level and income. It is important to consider that education and income are among the main determinants of tooth loss.
Regarding the socioeconomic determinants, the low educational level of the elderly in the city of Cruz Alta should be highlighted. The average number of men and women, average white and non-white individuals, and educational level of the elderly in this study are similar to those observed in the last national census for that city ${ }^{30}$. Also, the examiners were trained to collect the data in order to comply with a standard.

Regarding $\mathrm{FAI}^{17}$, the literature has shown some advantages, among them, simplicity for perception-based assessment, shorter application time, lower cost, and useful for use in epidemiological studies involving large populations ${ }^{18}$. The FAI is not a diagnostic tool, it is used to perform a TMD screening, allowing to classify the individual still at an early stage, as having symptoms compatible with TMD. On the other hand, this research presented some limitations. The first one refers to the transversal design, which does not allow to evaluate the temporality of the associations between TMD and the exploratory variables. In addition, the signs and symptoms of TMD and the mental responsiveness of the elderly were not clinically evaluated. Despite the limitations, the study design allows the generalization of data for comparisons with other home-based studies with a representative sample.

The interest in knowing the prevalence of TMD in the elderly population has been increasing, mainly in the last decades. This is because DTM plays an important role in the occurrence of OFP and in the incapacitation of daily activities ${ }^{6}$. Although the literature provides several epidemiological studies, there is no consensus as to its prevalence and its risk factors. These differences in prevalence can be caused by the design of the studies, by the heterogeneity of the diagnostic methods, by the lack of representativeness of the samples, among other reasons ${ }^{15,16}$. In any case, one of the important aspects of this work is the better understanding of the relationship between aging and oral health, especially in relation to TMD.

\section{CONCLUSION}

In this study, there was a high prevalence of TMD symptoms, predominantly mild. Age and dental losses were associated with TMD. The results suggest the need for improvement in the oral health conditions of the elderly and show the importance of further epidemiological studies on the prevalence of TMD in this population.

\section{REFERENCES}

1. Organização Mundial da Saúde. Guia Global das Cidades Amigas das Pessoas Idosas. 2007 Disponível em: <http://apps.who.int/iris/bitstream/10665/43755/3/9789899556867_ por.pdf $>$. Acesso em: 19 de novembro de 2016

2. Fechine BR, Trompieri N. O processo de envelhecimento: as principais alteraçóes que acontecem com o idoso com o passar dos anos. Rev Cient Int. 2012;1(7):106-94.

3. Gregersen FA. The impact of ageing on health care expenditures: a study of steepening. Eur J Health Econ. 2014;15(9):979-89.

4. Sánchez-García S, Heredia-Ponce E, Cruz-Hervert P, Juárez-Cedillo T, Cárdenas-Bahena A, García-Peńa C. Oral health status in older adults with social security in Mexico City: latent class analysis. J Clin Exp Dent. 2014;6(1):e29-35.

5. Boscato N, Schuch HS, Grasel CE, Goettems ML. Differences of oral health conditions between adults and older adults: a census in a Southern Brazilian city. Geriatr Gerontol Int. 2016;16(9):1014-20. 
6. Armijo-Olivo S, Pitance L, Singh V, Neto F, Thie N, Michelotti A. Effectiveness of manual therapy and therapeutic exercise for temporomandibular disorders: systematic review and meta-analysis. Phys Ther. 2016;96(1):9-25.

7. Okeson JP. Evolution of occlusion and temporomandibular disorder in orthodontics: past, present, and future. Am J Orthod Dentofacial Orthop. 2015;147(5 Suppl):S216-23.

8. De Giorgi I, Castroflorio T, Sartoris B, Deregibus A. The use of conventional transcutaneous electrical nerve stimulation in chronic facial myalgia patients. Clin Oral Investig. 2017;21(1):275-80

9. Marković D, Jeremic-Knezević M, Milekic B, Djurović-Koprivica D. The effect of age on distribution and symptomatology of craniomandibular dysfunction. Serbian Dent J. 2010;57(3):149-53

10. Rener-Sitar K, Celebić A, Mehulić K, Petricević N. Factors related to oral health related quality of life in TMD patients. Coll Antropol. 2013;37(2):407-13.

11. Cavalcanti MO, Lima CM, Lima JM, Gomes I, Goldim JR. Prevalência da disfunçấo temporomandibular em idosos náo institucionalizados. Estud Interdiscipl Envelhec. 2015;20(2):551-66

12. Riffel CD, Flores ME, Scorsatto JT, Ceccon LV, Conto F, Rovani G. Association of temporomandibular dysfunction and stress in university students. Int J Odontostomat. 2015;9(2):191-7.

13. Viana MO, Olegario NB, Viana MO, Silva GP, Santos JL, Carvalho ST. Effect of a physical therapy protocol on the health-related quality of life of patients with temporomandibular disorder. Fisioter Mov. 2016;29(3):507-14.

14. Sampaio NM, Oliveira MC, Ortega AO, Santos LB, Alves TD. Temporomandibular disorders in elderly individuals: the influence of institutionalization and sociodemographic factors. Codas. 2017;29(2):e20160114.

15. Boscato N, Almeida RC, Koller CD, Presta AA, Goettems ML. Influence of anxiety on temporomandibular disorders--an epidemiological survey with elders and adults in Southern Brazil. J Oral Rehabil. 2013;40(9):643-9.

16. Alzarea BK. Temporomandibular disorders (TMD) in edentulous patients: a review and proposed classification (Dr. Bader's Classification). J Clin Diagn Res. 2015;9(4):ZE6-9.

17. Fonseca DM, Bonfante G, Valle AL, Freitas SF. Diagnóstico pela anamnese da disfunção craniomandibular. Rev Gaucha Odontol. 1994;42(1):23-8.

18. Vasconcelos BC, Silva ED, Kelner N, Miranda KS, Silva A. Meios de diagnóstico das desordens temporomandibulares. Rev Cir Traumat Buco-Maxilo-Facial. 2002;2(1):49-57.

19. Rios AC, Rocha PV, Santos LB. Estudo comparativo entre Índice Anamnésico de Disfunçấo Temporomandibular e Inventário de Ansiedade Traço-Estado (IDATE) em mulheres idosas. Odontol Clín-Cient. 2012;11(3):221-7.

20. Ribeiro JA, de Resende CM, Lopes AL, Farias-Neto A, Carreiro Ada F. Association between prosthetic factors and temporomandibular disorders in complete denture wearers. Gerodontology. 2014;31(4):308-13.

21. Moura C, Cavalcante FT, Catão MH, Gusmão ES, Soares RS, Santillo PM. Fatores relacionados ao impacto das condiçóes de saúde bucal na vida diária de idosos, Campina Grande, Paraíba, Brasil. Pesq Bras Odontoped Clin Integr. 2011;11(4):553-9.

22. Camacho JG, Oltramari-Navarro PV, Navarro Rde L, Conti AC, Conti MR, Marchiori LL, et al. Signs and symptoms of temporomandibular disorders in the elderly. Codas. 2014;26(1):76-80.

23. Brasil. Projeto SB BRASIL 2010. Pesquisa Nacional de Saúde Bucal. Resultados Principais. Ministério da Saúde. 2012. Disponível em: <http://bvsms.saude.gov.br/bvs/ publicacoes/pesquisa_nacional_saude_bucal.pdf>. Acesso em: 17 de janeiro 2018.

24. Dallanora AF, Grasel CE, Heine CP, Demarco FF, Pereira-Cenci T, Presta AA, et al. Prevalence of temporomandibular disorders in a population of complete denture wearers. Gerodontology. 2012;29(2):e865-9.

25. Di Paolo C, Costanzo GD, Panti F, Rampello A, Falisi G, Pilloni A, et al. Epidemiological analysis on 2375 patients with TMJ disorders: basic statistical aspects. Ann
Stomatol (Roma). 2013;4(1):161-9.

26. De Rossi SS, Greenberg MS, Liu F, Steinkeler A. Temporomandibular disorders: evaluation and management. Med Clin North Am. 2014;98(6):1353-84.

27. Peltzer K, Hewlett S, Yawson A, Moynihan P, Preet R, Wu F, et al. Prevalence of loss of all teeth (edentulism) and associated factors in older adults in China, Ghana, India, Mexico, Russia and South Africa. Int J Environ Res Public Health. 2014; 11(11):11308-24.

28. Barbato PR, Peres MA, Höfelmann DA, Peres KG. Contextual and individual indicators associated with the presence of teeth in adults. Rev Saude Publica. 2015;49(27):110. Erratum in: Rev Saude Publica. 2015;49.

29. Organization WH. Oral Health Surveys: Basic Methods. $4^{\text {th }}$ ed. (Organization WH, ed.). Geneva; 1997.

30. Instituto Brasileiro de Geografia e Estatística. Censo Demográfico 2010: Características da população e domicílios - resultados gerais. 2011. Disponível em: <https:// biblioteca.ibge.gov.br/visualizacao/periodicos/93/cd_2010_caracteristicas_populacao_domicilios.pdf $>$. Acesso em: 19 de novembro de 2016.

31. DATASUS. Ministério da Saúde. Índice de Gini da renda domiciliar per capita - Rio Grande do Sul, 2010. 2010. Disponível em: <http://tanet.datasus.gov.br/cgi/ibge/ cnv/ginirs.def>. Acesso em: 19 de novembro de 2016.

32. Brasil. Ministério da Saúde. Manual do Instrumento de Avaliaçâo da Atençâo Primária à Saúde: Primary Care Assessment Tool PCATool-Brasil. 2010. Disponível em: <http://bvsms.saude.gov.br/bvs/publicacoes/manual_avaliacao_atencao_primaria. pdf>. Acesso em: 19 de novembro de 2016.

33. Jorge JH, Silva Junior GS, Urban VM, Neppelenbroek KH, Bombarda NH. Desordens temporomandibulares em usuários de prótese parcial removível: prevalência de acordo com a classificação de Kennedy. Rev Odontol UNESP. 2013;42(2):72-7.

34. Shetty R. Prevalence of signs of temporomandibular joint dysfunction in asymptomatic edentulus subjects: a cross-sectional study. J Indian Prosthodont Soc. 2010;10(2):96-101.

35. Almagro Céspedes I, Castro Sánchez AM, Matarán Peñarocha GA, Quesada Rubio JM, Guisado Barrilao R, Moreno Lorenzo C. [Temporomandibular joint dysfunctions, disability and oral health in a Community-dwelling elderly population]. Nutr Hosp. 2011;26(5):1045-51. Spanish.

36. Nguyen MS, Jagomägi T, Nguyen T, Saag M, Voog-Oras Ü. Symptoms and signs of temporomandibular disorders among elderly Vietnamese. Am J Orthod Dentofac Orthop. 2015;147(5):S216-23.

37. Gonzalez-Perez LM, Infante-Cossio P, Granados-Nunez M, Urresti-Lopez FJ, Lopez-Martos R, Ruiz-Canela-Mendez P. Deep dry needling of trigger points located in the lateral pterygoid muscle: efficacy and safety of treatment for management of myofascial pain and temporomandibular dysfunction. Med Oral Patol Oral Cir Bucal 2015;20(3):e326-33.

38. Calixtre LB, Moreira RF, Franchini GH, Alburquerque-Sendín F, Oliveira AB. Manual therapy for the management of pain and limited range of motion in subjects with signs and symptoms of temporomandibular disorder: a systematic review of randomised controlled trials. J Oral Rehabil. 2015;42(11):847-61.

39. Alzarea B. Prevalence of temporomandibular dysfunction in edentulous patients of Saudi Arabia. J Int Oral Heal. 2017;9(1):1-5.

40. Peres MA, Barbato PR, Reis SC, Freitas CH, Antunes JL. [Tooth loss in Brazil: analysis of the 2010 Brazilian Oral Health Survey]. Rev Saude Publica. 2013;47(Suppl 3):78-89. Portuguese.

41. Manfredini D, Poggio CE. Prosthodontic planning in patients with temporomandibular disorders and/or bruxism: A systematic review. J Prosthet Dent. 2017;117(5):606-13.

42. Miotto MH, Almeida CS, Barcellos LA. Impacto das condiçóes bucais na qualidade de vida em servidores públicos municipais. Ciên Saúde Coletiva. 2014;19(9):3931-40.

43. Unell L, Johansson A, Ekbäck G, Ordell S, Carlsson GE. Prevalence of troublesome symptoms related to temporomandibular disorders and awareness of bruxism in 65and 75-year-old subjects. Gerodontology. 2012;29(2):e772-9. 